\title{
PENGARUH LINGKUNGAN KERJA DAN BUDAYA ORGANISASI TERHADAP KEPUASAN KERJA KARYAWAN
}

\author{
Valeria Kiky Tiomantara dan I Gede Adiputra \\ Program Studi Manajemen Fakultas Ekonomi Universitas Tarumanagara, Jakarta \\ E-mail: valeria.115170366@stu.untar.ac.id; gedea@fe.untar.ac.id
}

\begin{abstract}
This research is conducted with the aim of examining the effect of work environment and organizational culture on employee job satisfaction at Aston Hotel in Pontianak. The respondents used in this study are 100 samples of active hotel employees. The primary data in this study are collected from questionnaires distributed online via GoogleForm, then processed using the SmartPLS software version 3.3.3. The sampling technique is carried out by purposive sampling method. The results of this study indicate that the work environment and organizational culture have a significant influence on employee job satisfaction.
\end{abstract}

Keywords: Work Environment, Organizational Culture, Job Satisfaction

Abstrak: Penelitian ini dilakukan dengan bertujuan untuk menguji pengaruh lingkungan kerja dan budaya organisasi terhadap kepuasan kerja karyawan Hotel Aston di Pontianak. Responden yang digunakan dalam penelitian ini sejumlah 100 sampel karyawan hotel yang aktif. Data primer pada penelitian ini dikumpulkan dari kuisioner yang disebarkan secara online melalui GoogleForm, kemudian diolah menggunakan bantuan software SmartPLS versi 3.3.3. Teknik pengambilan sampel dilakukan dengan metode purposive sampling. Hasil penelitian ini menunjukkan bahwa lingkungan kerja dan budaya organisasi memiliki pengaruh yang signifikan terhadap kepuasan kerja karyawan.

Kata Kunci: Lingkungan Kerja, Budaya Organisasi, Kepuasan Kerja

\section{LATAR BELAKANG}

Pada era modernisasi sekarang ini tingkatan persaingan antar perusahaan jasa semakin ketat. Untuk suatu perusahaan bisa bertahan dan tumbuh dalam keadaan tersebut, perusahaan wajib menciptakan inovasi peningkatan (Woods et al, 2017; Kim dan Koo, 2017) serta mengimplementasikan berbagai sumber daya yang ada terutama bagi perusahaan yang berorientasi pelanggan seperti hotel (Edghiem dan Mouzughi, 2017).

Keberhasilan suatu perusahaan dalam menggapai tujuannya tidak luput dari sumber daya manusia yaitu aset perusahaan berupa karyawan. Karyawan menjadi faktor sumber daya yang berarti bagi perusahaan sebab memiliki bakat, tenaga dan kreatifitas yang sangat diperlukan oleh perusahaan agar tercapai tujuan perusahaan tersebut.

Setiap karyawan berharap merasakan kenyamanan di tempat kerja dan kesesuaian budaya yang diterapkan agar dapat bertahan sampai bertahun-tahun hingga sampai pensiun nantinya. Hal ini menunjukan kalau memanglah lingkungan kerja yang baik sangat berarti bagi perusahaan untuk karyawannya supaya bisa terbentuk karyawan yang mempunyai kualitas baik serta mengukir prestasi-prestasi untuk karyawan dan perusahaannya. 
Kepuasan kerja dalam perhotelan merupakan hal penting yang dirasakan karyawan dalam bekerja. Seorang karyawan yang merasakan kepuasan kerja dalam pekerjaannya cenderung akan mempertahankan prestasinya.

Fenomena kepuasan kerja diketahui bahwa ada beberapa karyawan yang tidak memperoleh kepuasan kerja sehingga timbul sikap atau tingkah laku negatif, seperti tidak mengerjakan pekerjaan tepat waktu, sering datang terlambat, tidak hadir tanpa pemberitahuan, dan juga ada beberapa karyawan merasa perusahaan tidak memperhatikan hasil kerjanya sehingga menimbulkan rasa frustasi dan dapat berdampak negatif bagi hotel itu sendiri.

Lingkungan kerja merupakan wadah untuk menghasilkan hubungan kerja yang mengikat antara orang-orang yang ada didalam lingkungan perusahaan. Oleh karena itu, perusahaan hendaknya mengupayakan lingkungan kerja harus baik dan kondusif agar dapat menjadikan karyawan merasa betah berada di ruangan, merasa senang serta termotivasi untuk melaksanakan tugas yang diembannya sehingga kepuasan kerja akan terbentuk.

Fenomena lingkungan kerja adalah sebagian karyawan mengatakan kurangnya penerapan standar kesehatan dan keselamatan kerja (K3) bagi karyawan dalam melakukan pekerjaannya, seperti belum diterapkannya penggunaan masker pada karyawan laundry dan housekeeping. Dekorasi di ruangan kerja karyawan yang masih kurang menarik dan nyaman, pewarnaan ruangan serta dekorasi yang kurang mendukung sehingga menyebabkan ruangan terasa kurang elegan dan tidak hidup berdampak pada pergerakan karyawan menjadi kurang menyenangkan. Hal ini pula dapat menyebabkan karyawan mudah bosan yang akan memicu karyawan cepat lelah terhadap pekerjaan.

Adapun yang mengeluhkan fasilitas karyawan yang belum baik, seperti keadaan ruangan istirahat dan toilet karyawan yang kotor dan tidak dibersihkan, tidak adanya kendaraan operasional bagi karyawan hotel yang mana karyawan wanita yang masuk pada shift malam mengalami kesulitan untuk pulang ke rumah masing-masing, terutama bagi karyawan yang bertempat tinggal jauh dari hotel.

Ada juga karyawan yang tidak bersosialisasi satu sama lain atau bertegur sapa dan masih kurangnya pengawasan dari atasan atau pimpinan yang bertugas sehingga masih adanya ditemukan karyawan operasional yang bebas bermain handphone ataupun menggunakan komputer kantor untuk kepentingan pribadi yang menyebabkan karyawan tersebut mengabaikan pekerjaanya sendiri dan berdampak buruk kepada karyawan yang bekerja sama dengan karyawan tersebut.

Dalam mengelola industri perhotelan, manajer tentunya sudah menerapkan berbagai prinsip baik modern maupun tradisional. Akan tetapi, banyak pula yang kurang memberikan perhatian kepada budaya perusahaan (budaya organisasi), yang mana budaya organisasi merupakan salah satu tinjauan efektivitas, efisiensi dan produktivitas dalam perusahaan. Budaya organisasi memfokuskan diri pada pembelajaran tentang norma dan nilai yang tercermin pada perilaku atau tindakan organisasi itu sendiri (Sandora dan Adiputra, 2021).

Mengacu pada penelitian Sharma (2017) yang dalam jurnalnya menyatakan bahwa budaya organisasi memiliki pengaruh positif terhadap kepuasan kerja. Kemudian Narasuci et al (2018) mengungkapkan bahwa lingkungan kerja secara signifikan memiliki pengaruh terhadap kepuasan kerja. Serta diikuti Sunarsi (2020) dalam penelitiannya menghasilkan bahwa lingkungan kerja dan budaya organisasi memiliki pengaruh terhadap kepuasan kerja.

Merujuk dari hasil survei tersebut, menimbulkan pertanyaan apa yang mendasari karyawan dapat merasakan kepuasan di tempat kerja. Dengan telah diutarakan demikian, peneliti tertarik untuk meneliti lebih lanjut mengenai apa saja penyebab karyawan dapat merasakan kepuasan di tempat kerja. 


\section{KAJIAN TEORI}

\section{Herzberg's Two-Factor Theory}

Faktor yang mendorong kepuasan disebut motivator, sedangkan faktor yang berindikasi ketidakpuasan disebut faktor hygiene. Faktor motivator dan faktor hygiene tidak berlawanan dikarenakan faktor hygiene tersedia untuk mempertahankan produksi sedangkan motivator berfungsi untuk meningkatkan produksi sekaligus mempromosikan kepuasan kerja (Susan, 2018).

Faktor motivator digambarkan sebagai faktor yang terikat secara langsung dengan pekerjaan yang berkontribusi mengintensifkan dan memperbesar kualitas karyawan untuk bekerja lebih giat. Pada umumnya, faktor ini mempunyai efek jangka panjang dikarenakan terbentuk perasaan positif alih-alih menjadi ketidakpuasan.

Faktor lainnya yaitu faktor hygiene ialah apa yang mendasari suatu pekerjaan yang belum tentu menghasilkan kepuasan malah terkadang menimbulkan rasa tidak puas pada karyawan jika tidak hadir. Hal ini diantaranya kondisi kerja fisik, hubungan kerja, kebijakan organisasi, administrasi, kesehatan dan keamanan serta kompensasi.

Berlandaskan dengan teori ini, penulis menggunakan faktor hygiene seperti lingkungan fisik, keselamatan kerja, kesehatan kerja, dan teknologi atau peralatan sebagai parameter untuk meninjau lingkungan kerja akan berpengaruh terhadap kepuasan kerja karyawan. Perusahaan sebaiknya wajib menafsirkan situasi yang mendorong kerja sama antara atasan maupun bawahan sehingga tidak timbul kecanggunggan.

Faktor hygiene yang dikelola dengan baik akan meminimalisir ketidakpuasan kerja karyawan dimana karyawan merasa mendapatkan lingkungan kerja yang cocok sesuai dengan bidangnya ditambah budaya organisasi dalam perusahaan yang dirancang dan diterapkan sesuai kebutuhan bersama.

\section{Kaitan antara Lingkungan Kerja terhadap Kepuasan Kerja}

Kepuasan kerja karyawan ditunjukkan dengan terpenuhi atau tidaknya keinginan mereka terhadap pekerjaan yang dijalani dengan lingkungan kerja yang mendukung (Bhanu dan Babu, 2018). Karyawan yang merasakan kepuasan akan terinsipirasi untuk melibatkan diri secara efektif dalam proses pengambilan keputusan. Hal ini dapat menguntungkan pihak perusahaan maupun karyawan.

Dalam jurnal peneltian Niciejewska (2017), lingkungan kerja perlu memperhatikan keselamatan karyawan, keamanan kerja, hubungan kerja yang baik antar karyawan, pengakuan atas upaya dan kinerja terbaik sehingga menimbulkan rasa kepuasaan dan dihargai dalam perusahaan.

Setiap perusahaan memiliki kondisi lingkungan kerja yang berbeda dikarenakan berbagai faktor dari internal maupun eksternal. Oleh karena itu, tingkat kepuasan kerja pada tiap karyawan berbeda pula. Dengan menerapkan lingkungan kerja yang kondusif dapat membantu tercapainya kepuasan kerja.

Hubungan lingkungan kerja dengan kepuasan kerja didukung oleh beberapa penelitian seperti berikut ini. Kukiqi (2017) melakukan penelitian pengaruh lingkungan kerja terhadap kepuasan kerja di Kosovo dan ditemukan hasil bahwa lingkungan kerja berpengaruh signifikan terhadap kepuasan kerja karyawan. Tidak jauh berbeda dengan penelitian ini, Stella Ngozi Anasi (2020) menganalisis serta diperluas dengan variabel beban kerja dan hubungan kerja mendapatkan hasil bahwa lingkungan kerja berpengaruh positif terhadap kepuasan kerja. 


\section{Kaitan antara Budaya Organisasi terhadap Kepuasan Kerja}

Hubungan budaya organisasi dengan kepuasan kerja telah ditinjau oleh banyak peneliti. Budaya organisasi memegang peran penting terhadap kepuasan kerja. Keterlibatan dalam perusahaan yang memiliki birokrasi budaya organisasi yang baik akan memengaruhi tingkat kepuasan kerja yang mana merupakan faktor penting untuk keberhasilan perusahaan (Jigjiddorj et al, 2021).

Budaya organisasi yang buruk akan berimbas pada penurunan tingkat kepuasan kerja serta menurunkan produktivitas karyawan yang akhirnya akan memicu penurunan efisiensi dan efektifitas perusahaan. Budaya organisasi merupakan proses awal terbentuknya nilai individu dan kepercayaan bersama dalam perilaku karyawan (Hanny dan Adiputra, 2020). Perilaku karyawan berupa pola berpikir mereka baik disengaja maupun tidak sangat dipengaruhi oleh budaya organisasi.

Hubungan budaya organisasi dengan kepuasan kerja didukung oleh penelitian yang dilakukan Mesfin et al (2020) yang membuktikan bila responden merasakan pengaruh positif budaya organisasi terhadap kepuasan kerja. Penelitian selanjutnya oleh Purwadi et al (2020) menegaskan bahwa budaya organisasi berpengaruh signifikan terhadap kepuasan kerja.

\section{Hipotesis}

Berdasarkan teori Hezberg yang menyatakan secara keseluruhan kondisi kerja karyawan berhubungan pada lingkungan kerja dimana kenyamanan, fasilitas yang memudahkan pekerjaan, serta keamanan perlu dijaga agar lingkungan tetap kondusif dan karyawan bisa termotivasi. Karyawan yang mendapat fasilitas kemudahan dalam bekerja akan memberikan kualitas kepada perusahaan.

Hubungan antar rekan menjadi salah satu alasan karyawan bertahan karena terciptanya relasi yang baik antar pribadi dalam suatu perusahaan bukanlah hal yang mudah. Setiap pribadi memiliki emosi, pemikiran dan kepribadian yang berbeda-beda. Namun, jika perusahaan memiliki kebijakan organisasi yang terstruktur dan dapat diterima oleh seluruh karyawan, kesenjangan karyawan dapat diminimalisir.

Model penelitian yang terbentuk dalam penelitian ini adalah:

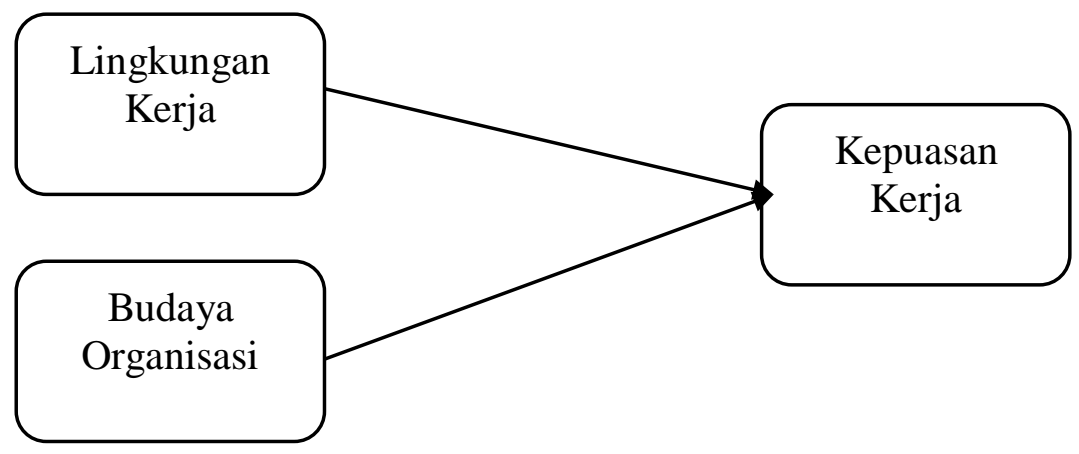

\section{Gambar 1 \\ Model Penelitian}

Hipotesis dalam penelitian ini dapat dirumuskan sebagai berikut:

Hipotesis $1(\mathrm{H} 1)$ : Terdapat pengaruh yang signifikan lingkungan kerja terhadap kepuasan kerja karyawan.

Hipotesis 2 (H2) : Terdapat pengaruh yang signifikan budaya organisasi terhadap kepuasan kerja karyawan. 


\section{METODOLOGI}

Berdasarkan tujuannya, penelitian ini dapat dikategorikan sebagai penelitian deskriptif, dengan menggunakan pendekatan kuantitatif. Penelitian ini menggunakan data primer yang dikumpulkan melalui metode survei, dengan menyebarkan kuesioner dalam bentuk Google form secara online. Populasi penelitian ini terdiri dari seluruh karyawan yang bekerja dalam Hotel Aston di Pontianak yang berjumlah 150 orang. Teknik pengambilan sampel yang diterapkan adalah non probability sampling, yakni secara purposive sampling. Peneliti menetapkan jumlah sampel sebanyak 100 orang. Data primer yang telah terkumpul selanjutnya akan dianalisis dengan teknik analisis Structural Equation Modeling (SEM), dan diolah dengan bantuan software SmartPLS versi 3.3.3. Di mana SmartPLS digunakan untuk menguji hubungan, pengaruh, dan kelayakan instrumen penelitian (Sholihin dan Ratmono, 2021). Analisis data dalam penelitian ini terdiri dari pengujian model pengukuran (uji validitas dan reliabilitas), uji model struktural (uji coefficient of determination, uji predictive relevance, dan uji effect size), uji Goodness of Fit $(\mathrm{GoF})$, dan uji hipotesis (path coefficient, tstatistic, dan p-value).

\section{HASIL ANALISIS DATA}

Diperoleh data 100 sampel responden yang memenuhi syarat dalam penelitian ini. Selanjutnya dari data tersebut diuji validitas (Convergent Validity dan Discriminant Validity) serta reliabilitasnya untuk memastikan kualitas data dari responden yang diterima.

Tabel 1

Hasil uji Average Variance Extracted (Convergent Validity)

\begin{tabular}{|l|c|}
\hline & AVE \\
\hline Lingkungan Kerja & 0,689 \\
\hline Budaya Organisasi & 0,623 \\
\hline Kepuasan Kerja & 0,673 \\
\hline
\end{tabular}

Sumber : Hasil olahan peneliti menggunakan SmartPLS versi 3.3.3

Terlihat dari tabel 1 bahwa setiap indikator dalam penelitian ini dinyatakan valid karena lolos pengujian validitas konvergen. Hal ini dijelaskan melalui nilai AVE pada setiap variabel, yaitu variabel lingkungan kerja, budaya organisasi, dan kepuasan kerja lebih besar daripada 0,5 . Suatu indikator dapat dikatakan valid apabila nilai AVE sama dengan atau lebih dari 0,5 (Hair Jr et al, 2020).

Tabel 2

Hasil Uji Cross Loading (Discriminant Validity)

\begin{tabular}{|c|c|c|c|}
\hline \multicolumn{4}{|c|}{ Cross Loading } \\
\hline & $\begin{array}{c}\text { Lingkungan } \\
\text { Kerja }\end{array}$ & $\begin{array}{c}\text { Budaya } \\
\text { Organisasi }\end{array}$ & $\begin{array}{c}\text { Kepuasan } \\
\text { Kerja }\end{array}$ \\
\hline LK1 & $\mathbf{0 , 8 3 1}$ & 0,433 & 0,495 \\
\hline LK2 & $\mathbf{0 , 8 0 4}$ & 0,385 & 0,456 \\
\hline LK3 & $\mathbf{0 , 8 6 3}$ & 0,485 & 0,602 \\
\hline LK4 & $\mathbf{0 , 7 9 7}$ & 0,488 & 0,490 \\
\hline
\end{tabular}




\begin{tabular}{|l|l|l|l|}
\hline LK5 & $\mathbf{0 , 8 4 1}$ & 0,493 & 0,527 \\
\hline LK6 & $\mathbf{0 , 8 4 3}$ & 0,497 & 0,509 \\
\hline BO1 & 0,553 & $\mathbf{0 , 7 6 3}$ & 0,511 \\
\hline BO2 & 0,422 & $\mathbf{0 , 8 0 2}$ & 0,580 \\
\hline BO3 & 0,464 & $\mathbf{0 , 7 8 4}$ & 0,649 \\
\hline BO4 & 0,427 & $\mathbf{0 , 7 6 3}$ & 0,597 \\
\hline BO5 & 0,403 & $\mathbf{0 , 8 0 9}$ & 0,610 \\
\hline BO6 & 0,400 & $\mathbf{0 , 8 1 5}$ & 0,608 \\
\hline KK1 & 0,495 & 0,717 & $\mathbf{0 , 8 2 1}$ \\
\hline KK2 & 0,537 & 0,677 & $\mathbf{0 , 8 9 1}$ \\
\hline KK3 & 0,568 & 0,679 & $\mathbf{0 , 8 5 5}$ \\
\hline KK4 & 0,460 & 0,465 & $\mathbf{0 , 7 6 1}$ \\
\hline KK5 & 0,448 & 0,495 & $\mathbf{0 , 7 7 7}$ \\
\hline KK6 & 0,539 & 0,618 & $\mathbf{0 , 8 1 0}$ \\
\hline Sub
\end{tabular}

Sumber : Hasil olahan peneliti menggunakan SmartPLS versi 3.3.3

Dilihat dari tabel 2 mengenai hasil uji cross loading diatas, dapat disimpulkan bahwa masing-masing indikator dari setiap variabel dalam penelitian ini dinyatakan valid, sehingga seluruh indikator tersebut dapat digunakan untuk penelitian ini. Setiap indikator dinyatakan lolos pengujian validitas diskriminan apabila memiliki nilai cross loading setiap konstruk lebih besar dibandingkan konstruk yang lainnya (Sholihin dan Ratmono, 2021).

\section{Tabel 3}

Hasil Uji Reliabilitas

\begin{tabular}{|l|c|c|}
\hline & Cronbach's Alpha & $\begin{array}{c}\text { Composite } \\
\text { Reliability }\end{array}$ \\
\hline Lingkungan Kerja & 0,910 & 0,930 \\
\hline Budaya Organisasi & 0,879 & 0,908 \\
\hline Kepuasan Kerja & 0,903 & 0,925 \\
\hline
\end{tabular}

Sumber : Hasil olahan peneliti menggunakan SmartPLS versi 3.3.3

Suatu indikator dinyatakan reliabel apabila nilai Cronbach's Alpha dan Composite Reliability lebih besar dari 0,7 (Nasution et al, 2020). Merujuk pada tabel 3, nilai dari Cronbach's Alpha dan Composite Reliability tiap-tiap variabel laten sudah melebihi nilai 0,7.

Setelah melakukan pengujian model pengukuran (uji validitas dan uji reliabilitas), selanjutnya dilakukan uji model struktural struktural (uji coefficient of determination, uji predictive relevance, dan uji effect size), uji Goodness of Fit, dan uji hipotesis (path coefficient, t-statistic, dan p-value).

\section{Tabel 4}

\section{Hasil Uji Koefisien Determinasi $\left(\mathbf{R}^{2}\right)$}

\begin{tabular}{|l|c|c|}
\hline & $\mathrm{R}$ Square & $\mathrm{R}$ Square Adjusted \\
\hline Kepuasan Kerja & 0,626 & 0,619 \\
\hline \multicolumn{2}{l}{ Sumber: Hasil olahan peneliti menggunakan SmartPLS versi 3.3.3 }
\end{tabular}


Berdasarkan hasil uji koefisien determinasi $\left(\mathrm{R}^{2}\right)$ pada tabel 4 diatas, diketahui nilai $\mathrm{R}^{2}$ sebesar 0,626, yang mana mengindikasikan bahwa variabel kepuasan kerja bisa dijelaskan oleh variabel lingkungan kerja dan budaya organisasi sebesar $62,6 \%$ dan sisanya $37,4 \%$ dapat dijelaskan oleh variabel lainnya. Selanjutnya, klasifikasi nilai $\mathrm{R}^{2}$ pada penelitian ini termasuk kategori sedang karena berada diatas 0,5 dan kurang dari 0,7. Semakin tinggi nilai $\mathrm{R}^{2}$, maka semakin besar pula hubungan variabel bebas terkait dengan variabel terikat (Bujang et al, 2018).

\section{Tabel 5}

Hasil Uji Predictive Relevance $\left(\mathrm{Q}^{2}\right)$

\begin{tabular}{|l|c|}
\hline & $\mathrm{Q}^{2}$ \\
\hline Kepuasan Kerja & 0,404 \\
\hline
\end{tabular}

Sumber: Hasil olahan peneliti menggunakan SmartPLS versi 3.3.3

Berdasarkan hasil uji analisis predictive relevance $\left(\mathrm{Q}^{2}\right)$ pada tabel 5, dapat dijelaskan bahwa nilai $\mathrm{Q}^{2}$ dari variabel kepuasan kerja adalah 0,404 . Angka ini lebih besar dari 0 (nol) sehingga dapat dinyatakan model dalam penelitian ini bersifat predictive relevance, artinya variabel kepuasan kerja dapat memprediksi variabel lingkungan kerja dan budaya organisasi dengan baik. Predictive relevance merupakan sarana untuk menguji nilai model struktural relevansi prediktif (Sarstedt et al, 2019).

\section{Tabel 6}

Hasil Uji Effect Size $\left(\mathbf{F}^{2}\right)$

\begin{tabular}{|l|c|}
\hline & Effect Size $\left(\mathrm{F}^{2}\right)$ \\
\hline Lingkungan Kerja & 0,156 \\
\hline Budaya Organisasi & 0,641 \\
\hline
\end{tabular}

Sumber: Hasil olahan peneliti menggunakan SmartPLS versi 3.3.3

Uji effect size adalah sarana menguji tingkat setiap variabel eksogen terhadap variabel endogen, dengan standar nilai $\mathrm{F}^{2}$ efek kecil yaitu $0,02,0,15$ berefek sedang, dan 0,35 artinya berefek kuat (Yahaya dkk, 2019).

Berdasarkan hasil uji effect size $\left(\mathrm{F}^{2}\right)$ pada tabel 6, dapat diuraikan jika lingkungan kerja berefek sedang terhadap kepuasan kerja dengan nilai $\mathrm{F}^{2}$ sebesar 0,156 , sedangkan budaya organisasi mempunyai efek yang sangat kuat terhadap kepuasan kerja dengan nilai $\mathrm{F}^{2}$ sebesar 0,641. Demikian dapat dikatakan pula variabel eksogen lingkungan kerja dan budaya organisasi memiliki efek terhadap variabel endogen kepuasan kerja.

$$
\begin{aligned}
\text { GoF } & =\sqrt{\overrightarrow{\mathrm{R}^{2}} \times \overrightarrow{\mathrm{AVE}}} \\
\mathrm{GoF} & =\sqrt{0,626 \times 0,662} \\
\mathrm{GoF} & =0,644
\end{aligned}
$$

Berdasarkan perhitungan manual diatas, dapat disimpulkan bahwa model dalam penelitian ini memenuhi syarat GoF serta memiliki kecocokan yang besar karena hasil yang didapatkan senilai 0,644 dimana lebih besar dari 0,36. 
Tabel 7

Hasil Uji Hipotesis Path Coefficients, T-Statistic, dan P-Value

\begin{tabular}{|l|c|c|c|}
\hline & $\begin{array}{c}\text { Path } \\
\text { Coefficients }\end{array}$ & T-Statistic & P-Value \\
\hline Lingkungan Kerja => Kepuasan Kerja & 0,291 & 4,397 & 0,000 \\
\hline Budaya Organisasi => Kepuasan Kerja & 0,591 & 2,078 & 0,038 \\
\hline
\end{tabular}

Sumber: Hasil olahan peneliti menggunakan SmartPLS versi 3.3.3

Sholihin dan Ratmono (2021) mengatakan pengujian hipotesis pada model SEM dengan PLS dapat dilakukan dengan membandingkan nilai t-stastistic dengan p-value. Suatu hipotesis dikatakan diterima dan antar variabel memiliki pengaruh yang signifikan jika nilai tstatistic lebih besar dari 1,96, dengan p-value kurang dari 0,05.

Mengacu pada tabel 7, dapat dilihat nilai t-statistic dari lingkungan kerja terhadap kepuasan kerja sebesar 4,397 yang artinya lebih besar dari 1,96 dengan nilai p-value 0,000 yang berarti lebih kecil dari 0,05 . Kemudian nilai path coefficients dari lingkungan kerja terhadap kepuasan kerja sebesar 0,291 yang menunjukkan bahwa lingkungan kerja memiliki hubungan yang kuat dan positif terhadap kepuasan kerja. Sehingga berdasarkan hasil pengujian hipotesis, dapat disimpulkan bahwa $\mathrm{H} 1$ dalam penelitian ini diterima dan memiliki pengaruh yang signifikan antar variabel.

Nilai t-statistic dari budaya organisasi terhadap kepuasan kerja sebesar 2,078 yang artinya lebih besar dari 1,96 dengan nilai p-value 0,038 yang berarti lebih kecil dari 0,05. Kemudian nilai path coefficients dari budaya organisasi terhadap kepuasan kerja sebesar 0,591 yang menunjukkan bahwa budaya organisasi memiliki hubungan yang kuat dan positif terhadap kepuasan kerja. Sehingga berdasarkan hasil pengujian hipotesis, dapat disimpulkan bahwa H1 dalam penelitian ini diterima dan memiliki pengaruh yang signifikan variabel independen terhadap variabel dependen.

\section{DISKUSI}

\section{Pengaruh lingkungan kerja terhadap kepuasan kerja karyawan}

Hasil pengujian hipotesis pertama (H1) menjelaskan variabel lingkungan kerja memiliki hubungan kuat positif dan signifikan terhadap kepuasan kerja. Hal ini didukung oleh indikator lingkungan kerja yang paling mempengaruhi kepuasan kerja, yaitu lingkungan kerja saya memiliki sistem keamanan yang ketat. Pernyataan tersebut disertai dengan alasan dikarenakan dengan memperketat sistem keamanan di lingkungan kerja dapat menjamin rasa aman dan terjaganya kualitas kerja individu serta meminimalisir kejahatan yang tidak diinginkan.

Lingkungan kerja merupakan aspek penting yang dapat menarik karyawan agar bekerja lebih giat dan bertahan lama. Karena biasanya karyawan akan betah jika kondisi lingkungan kerja yang dirasakan nyaman dan tidak tertekan. Karyawan dengan emosional yang baik dapat mengatur tempat kerja menjadi damai dan nyaman untuk bekerja sehingga dapat mengurangi kesalahpahaman antar rekan dan hubungan interpersonal tetap terjaga. Semakin baik lingkungan kerja yang dimiliki perusahaan, maka semakin besar kepuasan kerja yang dirasakan.

Hasil ini serupa dengan penelitian Meida Sari (2020) yang menyatakan bahwa kepuasan kerja dipengaruhi secara positif dan signifikan oleh lingkungan kerja. Pada 
penelitian tersebut mengatakan bahwa lingkungan kerja yang baik dapat meningkatkan kepuasan kerja di perusahaan.

\section{Pengaruh budaya organisasi terhadap kepuasan kerja karyawan}

Pengujian hipotesis kedua menampilkan jika budaya organisasi memiliki hubungan kuat positif dan signifikan terhadap kepuasan kerja. Hal ini didukung oleh salah satu indikator budaya organisasi yang berkontribusi paling besar, yakni saya memberikan masukan/ide untuk meningkatkan mutu perusahaan. Pernyataan tersebut didasari alasan karena dalam bekerja seorang karyawan tentunya memiliki rasa ingin mengembangkan nama perusahaan dengan berpartisipasi aktif memberi masukan/ide.

Dalam beberapa hal penting atau darurat kepentingan perusahaan perlu untuk diutamakan, seperti sesama rekan kerja seharusnya memiliki rasa solidaritas yang tinggi. Dengan begitu terdapat beberapa aturan di tempat kerja yang diciptakan sehingga membuat rasa kepuasan kerja menjadi maksimal.

Hasil penelitian ini sejalan dengan riset Rismayadi et al (2020) yang mengatakan bahwa secara partial budaya organisasi memiliki pengaruh positif dan signifikan terhadap kepuasan kerja. Pada penelitian ini variabel budaya organisasi merupakan yang dominan berpengaruh terhadap kepuasan kerja.

\section{KESIMPULAN}

\section{Saran} berikut :

Berdasarkan hasil dalam penelitian ini, maka peneliti memberikan saran sebagai

1. Lingkungan kerja memiliki pengaruh positif dan signifikan terhadap kepuasan kerja, sehingga disarankan kepada pihak Hotel Aston Pontianak agar terus menciptakan lingkungan kerja yang kondusif dan nyaman. Hal ini dapat dilakukan dengan menciptakan suasana kerja yang tenang antara atasan maupun bawahan.

2. Budaya organisasi memiliki pengaruh positif dan signifikan terhadap kepuasan kerja, sehingga peneliti menyarankan agar pihak manajemen Hotel Aston Pontianak selalu konsisten menerapkan budaya kerja yang baik. Hal ini dapat dilakukan dengan lebih mengutamakan kepentingan umum serta menginovasi karyawan.

3. Peneliti menyarankan kepada penelitian selanjutnya agar melibatkan variabel-variabel lain yang memiliki pengaruh terhadap kepuasan kerja karyawan sehingga penelitian lebih berkembang. Karena nilai $\mathrm{R}^{2}$ dalam penelitian ini sebesar $62,6 \%$ dan sisanya $37,4 \%$ yang dapat dijelaskan oleh variabel lainnya yang tidak diteliti dalam penelitian ini.

4. Peneliti juga menyarankan untuk penelitian selanjutnya supaya memperluas sampel agar hasil penelitian lebih mencerminkan karakteristik populasi yang dominan.

\section{DAFTAR PUSTAKA}

Anasi, Stella. N. (2020). Perceived influence of work relationship, work load and physical work environment on job satisfaction of librarians in South-West, Nigeria. Global Knowledge, Memory and Communication.

Bhanu, M. V. V., \& Babu, S. P. (2018). Impact of work environment and job stress towards job satisfaction. IOSR Journal of Business and Management (IOSR-JBM), 20(2), 0107. 
Bujang, M. A., Sa'at, N., \& Bakar, T. M. I. T. A. (2018). Sample size guidelines for logistic regression from observational studies with large population: emphasis on the accuracy between statistics and parameters based on real life clinical data. The Malaysian journal of medical sciences: MJMS, 25(4), 122.

Edghiem, F. and Mouzughi, Y. (2017), "Knowledge-advanced innovative behavior: a hospitality service perspective", International Journal of Contemporary Hospitality Management, Vol. 30 No. 1, pp. 197-216.

Hair, J. F., Howard, M. C., \& Nitzl, C. (2020). Assessing measurement model quality in PLSSEM using confirmatory composite analysis. Journal of Business Research, 109 (August 2019), 101-110.

Hair, J. F., Risher, J. J., Sarstedt, M., \& Ringle, C. M. (2019). When to use and how to report the results of PLS-SEM. European Business Review.

Hanny, Chyntia, and I Gede Adiputra. (2020). "Pengaruh Budaya Organisasi Dan Disiplin Kerja Terhadap Kinerja Karyawan PT Multikarya Saranaperkasa Jakarta." Jurnal Manajerial Dan Kewirausahaan 2.1: 215-221.

Herzberg, F. (2005). Motivation-hygiene theory. Organizational behavior one: Essential theories of motivation and leadership, eds JB Miner, ME Sharpe Inc, New York, 6174.

Jigjiddorj, S., Zanabazar, A., Jambal, T., \& Semjid, B. (2021). Relationship between organizational culture, employee satisfaction and organizational commitment. Les Ulis: EDP Sciences.

Kim, M.S. and Koo, D.W. (2017), "Linking LMX, engagement, innovative behavior, and job performance in hotel employees", International Journal of Contemporary Hospitality Management, Vol. 29 No. 12, pp. 3044-3062.

Kukiqi, E. (2017). Environmental conditions and work satisfaction in institutions in the Republic of Kosovo. International Journal of Education and Research, 5(7), 187-192.

Mesfin, D., Woldie, M., Adamu, A., \& Bekele, F. (2020). Perceived organizational culture and its relationship with job satisfaction in primary hospitals of Jimma zone and Jimma town administration, correlational study. BMC Health Services Research, 20, $1-9$.

Narasuci, W., Setiawan, M., \& Noermijati, N. (2018). Effect of work environment on lecturer performance mediated by work motivation and job satisfaction. Jurnal Aplikasi Manajemen, 16(4), 645-653.

Nasution, M. I., Fahmi, M., \& Prayogi, M. A. (2020, March). The Quality of Small and Medium Enterprises Performance Using the Structural Equation Model-Part Least Square (SEM-PLS). In Journal of Physics: Conference Series (Vol. 1477, No. 5, p. 052052). IOP Publishing.

Niciejewska, M. (2017). Difficulties in work safety management in a company producing steel flat bars. Production Engineering Archives, 17.

Purwadi; Darma, Dio Caisar; Febrianti, Widya; Mirwansyah, Dedy. (2020). Exploration of Leadership, Organizational Culture, Job Satisfaction, and Employee Performance. Technium Soc. Sci. J., 6, 116.

Rismayadi, B., Faddila, S. P., \& Maemunah, M. (2020). The influence of work motivation, leadership and organizational culture on job satisfaction in industrial estate in Karawang. International Journal of Psychosocial Rehabilitation, 24(7).

Sandora, Erika, and I Gede Adiputra. (2021). "Pengaruh Konflik Dan Stres Terhadap Kinerja Karyawan Kap, Diintervening Oleh Budaya Organisasi." Jurnal Manajerial Dan Kewirausahaan 3.2: 360-370. 
Sari, M. (2020, November). The Effect of Work Environment and Job Burnout on Job Satisfaction With Perceived Organization Support as Moderating to Employees at the secretariat Staff of the Regional Parliament of West Sumatra Province. In The Fifth Padang International Conference On Economics Education, Economics, Business and Management, Accounting and Entrepreneurship (PICEEBA-5 2020) (pp. 884-890). Atlantis Press.

Sharma, P. (2017). ORGANIZATIONAL CULTURE AS A PREDICTOR OF JOB SATISFACTION: THE ROLE OF AGE AND GENDER. Management : Journal of Contemporary Management Issues, 22(1), 35-48.

Sholihin, M., \& Ratmono, D. (2021). Analisis SEM-PLS dengan WarpPLS 7.0 untuk Hubungan Nonlinier dalam Penelitian Sosial dan Bisnis. Penerbit Andi.

Sunarsi, D. (2020). The Analysis of The Work Environmental and Organizational Cultural Impact on The Performance and Implication of The Work Satisfaction. Jurnal Ilmiah Ilmu Administrasi Publik, 9(2), 237-246.

Susan, N. U. (2018). Motivation and human resources in libraries. International Journal of Knowledge Content Development \& Technology, 8(3), 29-40.

Woods, S.A., Mustafa, M.J., Anderson, N. and Sayer, B. (2017), "Innovative work behavior and personality traits: examining the moderating effects of organizational tenure", Journal of Managerial Psychology, Vol. 33 No. 1, pp. 29-42.

Yahaya, M. (2019). Partial Least Square Structural Equation Modeling (PLS- SEM): A NOTE FOR BEGINNERS. 